\title{
Milestone of World Pandemics: A Review on Remedy for COVID-19 Diseases to Revitalize Human Race from Deadly Corona Virus
}

\author{
Adedayo Olajide Ajayi \\ Department of Microbiology, Adekunle Ajasin University, P.M.B 01, Akungba-Akoko, Ondo State, Nigeria \\ Director, Center for Drug Development and Infectious Diseases Research (CDDIDR), Adekunle Ajasin University, \\ Akungba-Akoko Ondo State, Nigeria \\ Email: olajide.ajayi@aaua.edu.ng,jidet02@yahoo.com \\ ORCID ID: https://orcid.org/0000-0002-5309-2653
}

\author{
Article History \\ Received: 13 January, 2021 \\ Revised: 26 February, 2021 \\ Accepted: 10 April, 2021 \\ Published: 14 April, 2021 \\ Copyright (C) 2021 ARPG \& \\ Author \\ This work is licensed under \\ the Creative Commons \\ Attribution International

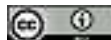 \\ Commons Attribution \\ License 4.0
}

\begin{abstract}
Viruses are microscopic organisms that can only grow within living host cells. Various types of animals such as Rats, Bat, Cows, snakes, and related wild animals can serve as vehicles of transmission of this group of organisms. Novel SARS-CoV-2 belongs to the Coronaviridae family that was reported to have emanated from Wuhan, China in December 2019. It alerts world response against strange viral respiratory disease. As the world reflects on pandemics historically. Epidemics like the London plague of 1665 and the Plague that emanates from Marseille, France of 1720 claimed millions of lives. Among the most dreadful world pandemics are the "Antonine Plague" which occurred in 165AD and claimed 5 million lives in Egypt, Asia, Italy, and Greece. "Plague of Justinian" was reported to have occurred between the years 541 and 542. In addition to this, "The Flu Pandemic" is also referred to as Spanish flu ravaged the world during the year 1918 to 1920, which is about a century ago." 3 rd Plague of 1855" originated from China and was responsible for the death of 10 million Indians within one year." The Black Death" which is a 7 years long pandemic devastated the world between the years 1346 to 1353. It leads to the death of half of the global population and was by far the worst pandemic. HIV-AIDS has peak record deaths between 2005-2012. In the year 2019/2020 COVID-19 broke out severely than MERS-CoV and SARS-CoV which occurred in recent years. One possible best approach for the control of COVID-19 diseases caused by SARS-CoV-2 is to improve the hosts' immune system. Evidence shows that inflammatory conditions militate against the immune systems of COVID-19 patients. Some other control strategies will include the use of face masks, physical distancing, hand washing, or use of alcohol-based sanitizers and related personal hygiene are important to contain the diseases.
\end{abstract}

Keywords: COVID-19; Human race; Milestone; Pandemics; Remedy.

\section{Introduction}

Viruses are microscopic organisms that can only grow within living host cells in our diversified environment. They are unique in that they only replicate within the host cells to cause infection through their nucleic acid and related protein components with their encapsulated coat.

The virus by their physiological nature are protein molecule (DNA) covered by a layer of lipid (fat) which protects the internal components. multiplier cells. Viruses being a protein molecule is not killed but decay and disintegrate based on some environmental conditions like temperature and humidity. It is very fragile, in that the outer layer is made up of fat which can be dissolved by heat and above $25^{\circ} \mathrm{C}$ and alcohol based preparations made up of over $65 \%$ alcohol that is lethal for virus survival $[1,2]$. Various types of animals such as Rats, Bat, Cows, Snake and related wild animals can serve as vehicle of transmission of this group of organism.

Bats to be used for the purpose of this study are present in most parts of tropical zones of the world. They are involved in pollination of flowers and feed on some insect pest. Thus boosting agricultural productivity. Bats, such as Kitti's hog-nosed bat are extremely small mamals of size range 29 to $34 \mathrm{~mm}$ in length, $15 \mathrm{~cm}$ across the wings and 2-2.6 g in mass. Similarly, The largest forms of bats that partly belongs to Pteropus, also known as fruit bats or flying foxes. While there are also the giant forms called golden-crowned flying fox [3, 4]. Bats are capable of harbouring various pathogenic organisms that often results in epidemics or pandemics Hanadhita, et al. [4]. Indeed, they are more frequently implicated in zoonotic virus emergencies such as Ebola infections, Corona virus infections and related viral etiologic infetions [3].

Recently, the involvement of Bats and Snake was documented as reservoir Corona virus which causes the global pandemic of COVID 19 that broke out during the towards December, 2019 through the first quarter of the year 2020. There are different viral species that can cause some upper respiratory tract infections in humans. This include alphacoronaviruses $\mathrm{HCoV}-229 \mathrm{E}$ and $\mathrm{HCoV}-\mathrm{NL} 63$, and betacoronaviruses HCoV-HKU1 and HCoV-OC43. 
Recently, additional pathogenic Corona virus strains were detected and identified. These were Severe Acute Respiratory Syndrome Coronavirus (SARS-CoV) and Middle East Respiratory Syndrome Coronavirus (MERS$\mathrm{CoV})$.

SARS-CoV was reported long ago in China in February 2003, and 4 months later, >8000 cases had been reported with about 800 deaths in 27 different countries worldwide. SARS-CoV is associated with wildlife meat industry.

Human-to-human transmission follows and can lead to large numbers of infected patients and is considered the main route of transmission in large-scale epidemics. The novel coronavirus (2019-nCoV) from Wuhan, China, has recently caused over 500 confirmed cases of human infections and at least 17 deaths in China as at February/March, 2020 (https://www.cdc.gov/coronavirus/novel-coronavirus-2019.html; [5].

MERS-CoV is closely related to SARS-CoV based on some phylogenetic analysis and source of infection, which are bats as reported from various countries. This indicates that bats may represent an important reservoir of these viruses. The occurrence of MERS-CoV was first reported in 2012 in Saudi Arabia and then spread to other countries causing hundreds of deaths. Clinical features of MERS-CoV are similar to SARS-CoV, although this virus has also been associated with several extrapulmonary manifestations, such as severe renal complications.

There are also numerous confirmed cases of 2019-nCoV infections in other countries as well as United States. Many of the symptoms caused by $2019-\mathrm{nCoV}$, such as acute respiratory syndrome, are similar to those that resulted from coronavirus infection known as severe acute respiratory syndrome (SARS-CoV). SARS-CoV emerged in 2002 to 2003 and transmitted among humans, causing over 8,000 confirmed cases of human infections and about 800 deaths at initial stage of report in early months of the year, $2020[6,7]$.

The principle of disease control varies with the Physiology of microbes involved and some epidemiological factors. Molecular biologist, Microbiologist including Virologist and other Scientist have engaged in serious laboratory works, virtual experimentations and robust discussions both locally and at international level to save human race from the destruction of this deadly pandemic. Gradually, you can agree that some tips were already given on conditions that are not favourable for the survival of this human race wrecking aetiologic agent. In terms of its trend at low temperature, adaptable $\mathrm{pH}$, where by alkaline medium will not favor it's survival. And of course, a major issue is the receptor binding site of the organism to the host cells.

In some recent studies, Coronaviruses (SARS-CoV, MERS-CoV, SARS-COV-2) receptor binding domain(RBD) only attaches and predominantly expressed to Angiotensin converting enzyme (ACE2) in respiratory tracts (upper and lower) as well as intestines, testis, and kidney (Wan et al. 2020, Li et al., 2020). Other routes of transmission like fecal sources excluding food, properly kept anyway, are also possible being new virus under study. Nevertheless, personal hygiene plays major role here. Hence, we don't jump to conclusion. Based on this, antibodies and small molecular inhibitors are being considered to block the interaction of human receptor for SARS-CoV-2, Angiotensin-converting enzyme 2 ACE2 with RBD to eliminate the virus as way forward. We should recall that some dreaded disease including the common malaria wreaked havoc in populace before discovery of effective treatment drugs around the globe. Hence, as scientist, we will be progressive to get things done and find lasting solution to the current surge.

\section{Pathogenesis of Virus in Cells to Cause Infection}

Viruses can only develop intracellular within living host cells. Hence, it first find and attach to a host cell. This is followed by penetration and injection of genetic material into that cell.

Some form of replication will take place whereby, there will be synthesis of viral components. Copy viral DNA or the use of RNA can make viral proteins using host cell materials. Assembly takes place, whereby, additional viral particles is built from newly synthesized viral parts. The last stage is the release, that is escape of the host cell and search for new cells to infect.

\section{Microbiology of COVID-19}

SARS-CoV-2 is a novel virus. Whereby we had no knowledge of its existence or immunity to this pathogen when it was first discovered in late 2019. SARS-CoV-2 spreads so rapidly, thus making unique formidable challenges associated with combating this bioterrorific virus. Nevertheless, more efforts are being made to get better understanding that profers remedy for the covid-19 pandemic. SARS-CoV-2 belongs to Coronaviridae family.

Like MERS-CoV and SARS-CoV, it is a Betacoronavirus. Its likely originated in bats and can cause severe respiratory disease in humans. The genome of SARS-CoV-2 is $\sim 30 \mathrm{~kb}$ in size. It is an enveloped, positive-sense, single-stranded RNA virus [6]. Crown-like spike proteins of SARS-CoV-2 makes it possible for it to binds to ACE2 [8]. Many symptoms associated with COVID-19 are caused by the patients immune system, not the virus itself.

\section{Outbreak of COVID-19}

The outbreak of COVID-19 that initially appeared as a pneumonia-like infection was first detected in an hospital in a community known as Wuhan located in China during the month of December in year 2019 as the novel corona virus disease that was identified in that country forthwith.

The pathogen responsible for COVID-19 was identified as Severe Acute Respiratory Syndrome corona virus 2 (SARS-cov-2), a member of the corona virus family. Its morphological appearance shows the cellular body covered with spike that looks like a crown. This etiologic agent was reported to have emanated through some laboratory works from a community known as Wuhan, China. Coronavirus diseases that spread from this source sporadically 
around the globe has generated a lot of controversy on foul play as bioweapon as well of carelessness of prompt report of its origin through World Health Organization (WHO).

Covid-19 pandemic was caused by new (or novel) strain of corona virus, related to the viruses that caused the Severe Acute Respiratory Syndrome (SAR) diseases spread during the year 2001 to 2003 and Middle East Respiratory Syndrome (MERS) outbreaks that started in the year 2012 to the present time. The corona virus disease of 2019 was given the abbreviated name of COVID-19 by World Health Organization, (WHO) on the month of February 11, 2020 and later details were given as "Severe Acute Respiratory Syndrome Corona virus 2" (SARScoV-2) by the body known as International Committee on Taxonomy of Viruses (ICTV) because the virus is a genetic cousin of the corona virus. COVID-19 is an acronym and in its full form stands for corona virus disease of 2019. COVID-19 cases can manifest wide range of symptoms, which may appear within 2 to 14 days after contact with the virus. Observable symptoms include Cough, Sore throat, Fever, Sneezing, Difficulty with breathing, Tiredness, Persistent pain or pressure in the chest and Drowsiness.

Generally, other symptoms that may accompany these feelings includes running nose or nasal congestion, headache, conjunctivitis, diarrhea, loss of taste or smell or a rash on skin or discoloration of fingers or toes, aches and pains $[8,9]$. In order to avoid confusion, some symptoms related to COVID-19 cases were determined as described here (1) dry cough + sneeze can be as a result of air pollution (2) cough + mucus + sneeze + runny nose are symptoms of common cold (3) Cough + mucus + sneeze + runny nose + body ache + weakness + light fever are used to determine flu, while, (4) Dry cough + sneeze + body pain + weakness + high fever + difficulty breathing are major symptoms of coronavirus coupled with loss of taste or smell or a rash on skin or discoloration of fingers or toes as earlier enumerated $[8,9]$.

On a general note, there are two major routes by which people could be infected. That is, through secretion via facial and nasal routes of people at close range of less than 2 meters who can inhale through the lungs; and secondly touching of contaminated surfaces and shaking hands with an infected people coupled with touching eyes, mouth or nose. Since the corona virus disease (COVID-19) was first reported during the year 2019 in Wuhan, China, , it has spread rapidly across the globe, leading to over four million confirmed cases in six months. Nigeria Centre for Disease Control (NCDC), reported that on the 27th of February 2020, Nigeria confirmed its first case of COVID-19 [10]. Since then, the number of confirmed cases has gradually increased, with more sporadic cases reported across more states in Nigeria, other African countries, as well as the whole world.

\section{Historical Perspectives of World Pandemics}

According to Thorpe [11], the discovery of Yersinia pestis bacterium in skeletons found in a recently discovered plague pit proves that the outbreak of London plague also known as Great Plague of 1665 was bubonic.

In August 1665, from his two-room lodgings in Southwark, the chemist John Allin shared his devastating experience. A pit uncovered outside John Allins window that was dug together with New Churchyard Cemetery in east London and filled with plague dead in the confirmed the incidence. Some DNA test conducted also shows evidence that helps to identify of Yersinia pestis as an agent in the London plague, known as Great Plague of 1665 [11].

The symptoms of this illness at early stages are chills, thirst, headaches, shaking, nausea, drowsiness and loss of appetite. At later stages of the disease there are manifestations of vomiting, cold sweats, coughing up blood phlegm, diarrhoea and convulsions. The most telling symptoms were those which affected the victims' skin: blains, carbuncles, blisters and some related swellings [11]. Though, there are diseases with similar symptoms such as diphtheria, anthrax, typhoid, typhus, and measles [11].

In 1720, there was another deadly episode of diseases outbreak. This occurred when a ship was quarantined at the port in Marseille, France as a result of a strange infection whereby many people died on the ship. Deputy Mayor of Marseille lifted the quarantine to "help economy". This also caused 100,000 people died. More than half of Marseille died. This was the Great Plague of Marseille. They want to safeguard the economy to continue life. They told themselves "we will only move the silk and cotton on the ship into the city but not the infected people on the ship"

In bit to save the economy by lifting the quarantine, more than half of Marseille citizens died. Marseille is a major port city in the south of France. This diseases outbreak at the city of Marseille caused the death of 50,000 people, out of a total 90,000 population at that time. Many people died that there was no longer graves to bury them, whereby dead bodies littered the streets of Marseille, France, that period and nobody cares for economy again. This deadly experience is a warning to avoid prioritizing the "economy" above human safety and health. Because the economy can be recovered but the dead can never be revived. The world's worst pandemics of all times should be recalled at this period of world lockup transition in order to use history to mend our future.

Among this are,

1. “Antonine Plague" , also known as the Plague of Galen (named after Galen, the physician who discovered it) The Antonine Plague was reported to have occurred during the year $165 \mathrm{AD}$ to $180 \mathrm{AD}$. It caused the death of over 5 million lives. It was brought to the Roman Empire by troops who were returning from campaigns in the Near East in the past. The plague was experienced in the Asian countries and spread to other countries such as, Egypt, Greece and Italy. [12-16]. This plague led to the decline of the Roman Empire. 2.

2. "Plague of Justinian." Was named after the Emperor Justinian 1 and it affected about half of the population of Europe. This outbreak occurred during the year 541 to 542, whereby about 25 million people were dead 
in one year. The Greek physician Gallen (129-217 CE) was influenced by his diseases cocept of humorism, a medical system which relied on the treatment of diseases based upon bodily fluids composition known as "humors" [17, 18].

3. "The Flu Pandemic", otherwise known as The *Spanish Flu*. It was the worst pandemic in recent time caused by H1N1 virus. It is a common ancestor of human and classical swine H1N1 influenza viruses. It occurred during the year 1918 to 1920 [19]. It caused acute illness in 25 to $30 \%$ of estimated world's population at the period of report. Meaning that an estimated 500 million people which was the equivalence of one-third of the worlds population became infected with the virus as reported.

Corona virus kills the elderly mostly and immune-compromised individuals. But the Spanish flu respected no age group because of its infectivity among various age groups.

4. “The 3rd Plague of 1855" . Started from Yunnan, China, South West China. It leads to mortality of one million Indians within one year. This was during the 5th year of the Xianfeng Emperor of the Qingdynasty [20, 21].

5. “The Black Death." This worst diseases outbreak, that occurred between 1346-1353. It lasted 7 years long pandemic. It was caused by bubonic plague transmitted by fleas [22]. By that time, the world's population was 400million, then 200 million died. Half of the global population died. If the world was to end with a disease, it would end that time not with corona. It is said that during that plague, the living spent most of their time hurrying the dead in mass graves and yet others were left unburied [21, 22].

6. "HIV-AIDS" Tormented the world few decades ago. The disease rears its ugly head across the world. The peak record deaths were recorded between the year 2005 and 2012.

In 7 years, about 36 million people died [23-28]. There are other pandemics that ravaged the world like the 1629 to 1631 Italian plague, 1899 to 1923 cholera pandemic, Hong Kong flu - 1968 to 1969, Swine flu pandemic - 2009 to 2010, 1889 to 1890 flu pandemic, West African Ebola virus - 2013 to 2016, The Great Plague of London - 1665 to 1666 earlier described in this context.

SARS outbreak also occurred between 2002 and 2004, MERS-CoV outbreak in 2012. Zika virus epidemic occurred between 2015 to 2016. There is also 2017 to 2018 United States flu in which about 80,000 people died. The influenza-like-illness (ILI) was linked to a predominant strain of influenza H2N2.

And an influenza virus B was also detected during the spring period of March to May [21, 29]. In the present day Corona death is threatening, but much efforts are put in place to contain the diseases. So that the fatality will not be up to the previous pandemics.

\section{Incidence and Ante-incidence of Corona Virus Pandemic}

The study of Omulo, et al. [30], shows that the emergence of antimicrobial resistance (AMR) as a complex process which involves the interplay of human, environmental and pathogen-related factors with consequent demand for antimicrobial therapy [30-33].

Prevention and control of corona virus pandemics * Heat melts fat, hence, it is advisable to use water with temperature above $25^{\circ} \mathrm{C}$ for hands washing, clothes and related domestic appliances. Similarly, hot water lathers well and makes more foam. It can be more ideal under these circumstances. * Alcohol based sanitizers or mixture formulas with over $65 \%$ alcohol dissolves fat generally. Especially the external layer of the virus coated with lipids can be susceptible to this antigenic management. * Mixtures of 1-part bleach with 5 parts water can directly dissolve the protein. This is lethal to the virus from inside. * Oxygenated water is also valuable. This can be complementary to the use of alcohol, soap and chlorine. Peroxide too can dissolve the virus protein, but this have to be used pure since it can hurt the skin.

Basically, some of this components stated here are inclusive in formulation of standard sanitizers. At the onset of COVID-19 pandemic, the infectivity rate across the world is relatively low. The statistics obtained at the end of month February, 2020 across the globe are reflected below:

\section{Countries with Confirmed Cases: *CORONA VIRUS*}

China - 78,073 (2,715 deaths), South Korea - 1,261 (12 deaths), Japan - 863 (6 deaths), Italy - 357 (11 deaths), Iran - 139 (19 deaths), Singapore - 91, Hong Kong - 89 (2 deaths), United States - 57, Thailand - 40,Taiwan - 32 (1 death), Bahrain - 26, Australia - 23, Malaysia - 22, Germany - 18, Kuwait - 18, Vietnam - 16, France - 17 (2 deaths), United Arab Emirates - 13, United Kingdom - 13, Canada - 11, Macau - 10, Canary Islands - 5, Iraq - 5, Spain - 5, Oman - 4, India - 3, Philippines - 3 (1 death), Austria - 2, Croatia - 2, Israel - 2, Afghanistan - 1, Algeria - 1, Belgium - 1, Cambodia - 1, Egypt - 1, Finland - 1, Russia - 2, Lebanon - 1, Nepal - 1, Sri Lanka 1, Sweden - 1, Switzerland - 1, Pakistan -2, Nigeria -1 (Source: [34] Vanguard News Nigeria. - BREAKING news, February 29th, 2020 news).(February end statistics).

\section{Other Cautions on Corona Virus Infection Control}

Bactericides and antibiotics cannot be used against virus. This is because virus is not a living form of organism like bacteria. It is important to avoid shaking unused clothing and sheets that has been left over. This can raise the virus molecules to float in the air for up to 3 hours, and can cause havoc by lodging in in your nose. The suspension can glue to a porous surface for hours or days. Cool environment or artificial as air conditioners in houses and cars can also make virus molecule relatively stable. This is also paramount with dark humid environment. Nevertheless, 
dehumidified, dry, warm and bright environments are helpful to degrade Coronavirus faster. Its also good to keep nails short so that the virus does not hide there.

At the initial stage until recent time, the corona virus, the causative agent of COVID-19 is a novel virus that has no treatment drug nor approved vaccine for its control for relatively couple of months from the period it was first discovered during the month of December, 2019. Chloroquine, Hydroxychloroquine and Ivemectin are possible drugs for treating SARS-CoV-2 to control the hosts immune system.

The Mechanism of action of some drugs are on Immune Suppression, whereby Chloroquine and hydroxychloroquine reduce autophagy (self-regulated destruction of host cells) and interfere with Toll-like receptor (TLR) signaling and decrease cytokine production. This reduce and manage inflammation effectively. The immune responses are also improved. Evidence suggests that chloroquine and hydroxychloroquine may also interfere with the glycosylation of SARS-CoV-2 cellular receptors and prevent virus/cell fusion by increasing endosomal $\mathrm{pH}$. A trial involving 100 patients in China reported that chloroquine was effective at decreasing pneumonia and shortening the duration of disease. Larger controlled trials to determine the effectiveness of these medications as treatments for COVID-19 are taking place as we speak.

Remdesivir Another possible approach for treating SARS-CoV-2 helps prevent replication of the virus. If the viral genome isnt copied, the virus cant reproduce, and the infection will be cleared. It should be noted that this is not a one-size-fits-all approach. Not all antiviral medications work on all viruses. Microbes have unique, and often distinguishing, properties that must be taken into consideration when developing treatment plans [35, 36].

The Mechanism: Inhibition of Replication Machinery Remdesivir, broad-spectrum antiviral drug that inhibits RNA-dependent RNA polymerase, the virus-encoded enzyme responsible for copying SARS-CoV-2s genetic code. Blocking an enzyme necessary for RNA replication prevents the virus from making copies of original virion and allows the body to mount an effective response to eliminate it.

Remdesivir has shown prophylactic and therapeutic activity against MERS-CoV in non-human primates and invitro activity against SARS-CoV-2 $[35,37,38]$. The Data from the University of California Davis Medical Center in Sacramento, CA reported successful treatment of a female patient with COVID-19 using remdesivir. This patient had one of the first recorded community-spread COVID-19 infections in the United States [37].

Monoclonal Antibodies is another strategy for treating SARS-CoV-2 was designed to attack the virus directly. This can be done by locking a virus ability to recognize, attach to or penetrate host cells. This will prevent infection altogether. Human bodies can do this naturally through the production of antibodies. Antibodies are naturally produced when the body is exposed to infection and recoveries.

The Mechanism: Enhance Immune Recognition SARS-CoV-2 is a novel virus. That means people who havent been infected with it have no antibodies to this virus in their immune memory banks. But people who have recovered from COVID-19 infections do, and if functional copies (called monoclonal antibodies) can be engineered and reproduced in a laboratory setting, as substitute antibodies formulations to enhance the immune systems attack on SARS-CoV-2.

\section{Discussion and Recommendation}

There are diversified natural remedies experience in course of control COVID-19 outbreak control. Covid-19 was termed an incurable disease at the onset because it defied a lot of medications. No legitimate cure was found for the diseases for a relatively long time until the advent of vaccine formulations during the year 2021. Nevertheless, many people embark on local covid-19 formulas as convenient remedies to combat life threating infection.

One if such surveyed treatment includes the use of Hydroxychloroquine 200mg twice a day for 5 days; Azithromycin $500 \mathrm{mg}$ once a day for 5 days, Zinc sulfate $220 \mathrm{mg}$ for 5 days. On routine basis to build up the body immunity, Vitamin C-1000mg is usually administered. However, in confirmed cases of infection, drugs like, Chloroquine, turmeric, lemon, unripe pineapple and steam inhalation is combined. Meanwhile, this backed up spiritually with prayer. Traditionally, (Onion and Black seed/ oil, mixed together with addition of pure honey). This can be taken as 1 teaspoon, morning and Night, with one 1 Tablet of VitaminC-1000mg daily. Though, fruit preparations that are rich source of vitamin C, like lemon, Ginger and Turmeric powder can be administered and steam inhaled for this purpose.

Finally, the organism cannot survive alkaline conditions. Tangerine, pineapple, in addition to fruit earlier stated above can provide such alkaline condition to kill the virus. Apart from their vitamin $\mathrm{C}$ value and the antiinflammatory properties they possessed help to strengthen the body immunity and eliminate Corona virus.

One popular herbal remedy that being effectively used during covid-19 pandemic is the Black seed/oil. Few other nourishments are used to complement the treatment. Black Seed \& Oil one of the natural herbal remedies that was successfully tried for COVID-19 treatment in some instances, have some Antiviral activities: Antibacterial activities and its generally an infection killer.

Based on its medicinal properties, Black seed powder/oil have many health benefits in healing different terminal diseases ranging from hypertension, by lowering blood pressure, Arthritis and rheumatism, improves vision, Lowers Anxiety, Asthma and Cough, treats insomnia and HIV 1\&2 and not for somebody who is already down with AIDS, reduces the risk of heart disease, Shrinks Fibroid, treats Hepatitis and other stubborn viruses It improves memory, Cures Ulcer, helps diabetics, manages stretch marks on the skin as well as Strengthens the immune system. It is also reported as an excellent plant for general well-being.

Black seed has no side effect on body organs generally. Black seed can be grounded and mixed with black oil and put it inside original honey. One spoon can be administered morning and night for diseases treatment and control. 


\section{Conclusion}

Scientifically and historically, many diseases have ravaged the world in form of pandemics in the past decades and centuries. Covid-19 which comes up with its own challenge starting from China, during the month of December, 2019 soar high during the year 2020. The controversy of its origination as bioweapon generated a lot of worries considering the high rate of spread despite the militant approach the world over take to eliminate the deadly surge.

Nevertheless, these efforts yielded good result because scientist are finding clues on this novel virus as time passes bye and thus keeping the world as a whole on recovery path Extant measures were taken on daily basis to limit the transmission of the virus. This include, routine personal hygiene. It is important to wash hands with clean water. Use of water alone is not very effective in washing the virus off our hands. Hence, alcohol based product or sanitizers work better. But soap is most effective - since the virus detaches from the skin and falls apart easily in soapy water. Sanitizers are however bound to provide some antigenic protection for some time. Other measures taken in most countries to contain the surge of the pandemic is total shut down of the economy including schools, worship houses, relaxation joints, etc to avoid getting that compulsive exposure.

Travel, birthdays, marriages, burial and holiday bugs were also prevented to protect our people from undue expose to unnecessary risks and hazards. People generally take all precautions while at home and while outside for any important work. The principle of disease control globally, varies with the physiology of microbes involved and some epidemiological factors including history of the world pandemics.

Scientist generally plays vital role on research, enlightenment and management of covid-19 cases since the beginning of the pandemic spread till date. Some of the determined efforts that can help to overcome the surge of covid-19 include the formulation of vaccine. Similarly, some clinical data are pending whereby relevant companies and scientist isolated hundreds of virus-neutralizing antibodies from mice and recovered COVID-19 patients with hopes of initiating human trials when feasible. Covid-19 has been a big challenge to the world. Everyone have role to play as intensified in this report and sustain the post COVID-19 free society. We will overcome.

\section{References}

[1] Shanmugaraj, B., Siriwattananon, K., Wangkanont, K., Phoolcharoen, W., and Shanmugaraj, B., 2020. "Perspectives on monoclonal antibody therapy as potential therapeutic intervention for Coronavirus disease19 (COVID-19)." Asian Pac. J. Allergy Immunol., vol. 38, pp. 10-18.

[2] Donga, E. and Gardnera, L., 2020. "An interactive web-based dashboard to track COVID-19 in real time." The Lancet Infectious Diseases, vol. 20, pp. 533-534. Available: https://doi.org/10.1016/S1473$\underline{\text { 3099(20)30120-1 }}$

[3] Calisher, C. H., Childs, J. E., Field, H. E., Holmes, K. V., and Schountz, T., 2006. "Bats: important reservoir hosts of emerging viruses." Clin Microbiol Rev., vol. 19, pp. 531-545.

[4] Hanadhita, D., Satyaningtijas, A. S., and Priyono, S. A., 2017. "Bats as a viral reservoir: A short review of their Ecological Characteristics and Immune system." In Ist International Conference in One Health (ICOH 2017).

[5] Khan, S., Siddique, R., Shereen, M. A., Ali, A., Liu, J., Bai, Q., Bashir, N., and Xue, M., 2020. "The emergence of a novel coronavirus (SARS-CoV-2), their biology and therapeutic options." Journal of Clinical Microbiology, Available: https://jcm.asm.org/content/early/2020/03/05/JCM.00187-20

[6] Wan, Y., Shang, J., Graham, R., Baric, R. S., and Li, F., 2020. "Receptor recognition by the novel coronavirus from wuhan: An analysis based on decade-long structural studies of SARS coronavirus." Journal of Virology, vol. 94, pp. e00127-20.

[7] Wang, D., Hu, B., Hu, C., Zhu, F., Liu, X., Zhang, J., Wang, B., Xiang, H., Cheng, Z., et al., 2020. "Clinical characteristics of 138 hospitalized patients with 2019 novel coronavirus-infected pneumonia in Wuhan, China." Available: http://doi:10.1001/jama.2020.1585

[8] Yong, Z. Y., Chen, C., Zhu, S., Shu, C., Wang, D., Song, J., Song, Y., Zhen, W., Feng, Z., et al., 2020. "Isolation of 2019-nCoV from a stool specimen of a laboratory-confirmed case of the coronavirus disease 2019 (COVID-19)." China CDC Weekly, vol. 2, pp. 123-124.

[9] Chen, N., Zhou, M., Dong, X., Qu, J., Gong, F., Han, Y., Qiu, Y., Wang, J., Liu, Y., et al., 2020. "Epidemiological and clinical characteristics of 99 cases of 2019 novel coronavirus pneumonia in Wuhan, China: a descriptive study." Lancet, vol. 395, pp. 507-513.

[10] The Precision NG, 2020. "Home News News alert: Nigeria records first death from coronavirus." Available: http://theprecisionng.com/2020/03/news-alert-nigeria-records-first-death-coronavirus.html

[11] Thorpe, L., 2016. "Bill of Mortality for September 12th to 19th, 1665. The Great Plague of 1665."

[12] Gilliam, J. F., 1961. "The plague under marcus aurelius." The American Journal of philology, vol. 82, pp. 225-251.

[13] Bray, R. S., 2019. Armies of pestilence. Barnes and Nobel.

[14] Fears, J. R., 2004. "The Plague under Marcus Aurelius and the decline and fall of Roman Empire." Infectious Diseases Clinics of North America, vol. 18, pp. 65-67.

[15] Littman, R. J. and Littman, M. L., 1973. "Galen and the Antonine Plague." The American Journal of Philology, vol. 94, pp. 243-255.

[16] Raoult, D. and Drancourt, M., 2019. Paleomicromicrobiology. Springer.

[17] Baras, C., 2014. "The years of darkness." New Scientist, vol. 221, pp. 34-38. 
[18] Horgan, J., 2019. "Antonine plague. Ancient history encyclopedia." Available: https://www.ancient.eu/Antonine Plague

[19] Taubenberger, J. K., 2006. "The origin and virulence of 1918 Spanish influenza virus." Proc. Am Philos Soc., vol. 150, pp. 86-112.

[20] Bramanti, B., Dean, K. R., Walloe, L., and Stenseth, N. C., 2019. "The third plague pandemic in Europe." In Proceedings of the Royal Society B. Biological Sciences.

[21] Mark, J. J., 2020. "Reactions to plague in the ancient and medieval world. Ancient history encyclopeadia." Available: https://www.ancient.eu/article/1534/

[22] Cantor, N. F., 2015. In the wake of the plague: The black death and the world it made. Simon and Schuster.

[23] Centers for Disease Control and Prevention CDC, 1983. "Acquired immunodeficiency syndrome (AIDS): Precautions for health-care workers and allied professionals." MMWR Weekly, vol. 32, pp. 450-451.

[24] Centers for Disease Control and Prevention CDC, 1984. "Antibodies to a retrovirus etiologically associated with acquired immunodeficiency syndrome (AIDS)." Populations with Increased Incidences of the Syndrome, vol. 33, pp. 377-379.

[25] Mann, J. M., 1989. AIDS: A worldwide pandemic' in Current Topics in AIDS vol. 2. John Wiley and Sons: Gottlieb, M.S.

[26] The New York Times, 1990. "Ryan White Dies of AIDS at 18; his struggle helped pierce myths." Available: https://www.google.com/url?sa=t\&rct=j\&q=\&esrc=s\&source=web\&cd=\&cad=rja\&uact=8\&ved=2ahUKE wiWr9j0v9vvAhUHxIUKHVmdA1UQFjABegQIAhAD\&url=https\%3A\%2F\%2Fwww.nytimes.com\%2Fli brary\%2Fnational\%2Fscience\%2Faids\%2F040990sciaids.html\&usg=AOvVaw1Dw2FVE91dbH4SRBW_K7DK

[27] Roberts, B. D., 1994. "HIV antibody testing methods." Journal of Insurance Medicine, vol. 26, pp. 13-14.

[28] Centers for Disease Control and Prevention CDC, 2012. "CDC Global HIV/AIDS Milestones: On the Path to an AIDS-Free Generation." Available: https://stacks.cdc.gov/view/cdc/21211

[29] Reilly, B., 2009. Disaster and human history: Case studies in nature, society and catastrophe. McFarland and Co Inc.

[30] Omulo, S., Thumbi, S. M., Njenga, M. K., and Call, D. R., 2015. "A review of 40 years of enteric antimicrobial resistance research in Eastern Africa: what can be done better?" Antimicrobial Resistance and Infection Control, vol. 4, p. 1.

[31] Aminov, R. I., 2010. "A brief history of the antibiotic era: lessons learned and challenges for the future." Front Microbiol., vol. 1, p. 134.

[32] Saga, T., 2009. "Yamaguchi k. History of antimicrobial agents and resistant." Japan Med. Assoc. J., vol. 137, pp. 103-8.

[33] Shears, P., 2001. "Antibiotic resistance in the tropics: Epidemiology and surveillance of antimicrobial resistance in the tropics." Trans R. Soc. Trop. Med. Hyg., vol. 95, pp. 127-30.

[34] Vanguard, 2020. "Luxembourg reports first coronavirus case linked to Italy." Available: https://www.vanguardngr.com/2020/02/

[35] Coleman, C. M., Sisk, J. M., Mingo, R. M., Nelson, E. A., White, J. M., Frieman, M. B., and Coleman, C. M., 2016. "Coronavirus susceptibility to the antiviral remdesivir (GS-5734) is mediated by the viral polymerase and the proofreading exoribonuclease." J. Virol., vol. 90, pp. 8924-33.

[36] Totura, A. L., Bavari, S., and Totura, A. L., 2019. "Broad-spectrum coronavirus antiviral drug discovery." Expert Opin Drug Discov., vol. 14, pp. 397-412.

[37] Hagen, A., 2020. "Antimicrobials and COVID-19: Strategies for Treating a Pandemic. By a science communications specialist at ASM." Available: https://asm.org/Article/2020/March/Antimicrobials-andCOVID-19-Treatment-Strategies-f\#

[38] Li, H., Zhou, Y., Zhang, M., Wang , H., Zhao, Q., and Liu, J., 2020. "Updated Approaches Against SARSCoV-2." Antimicrob Agents Chemother, vol. 64, pp. e00483- 20. Available:

http://doi:10.1128/AAC.00483-20 